\title{
Culturally Responsive Curriculum and Pedagogy in the Commonwealth of the Northern Mariana Islands
}

\author{
Thomas Misco \\ Miami University
}

U. S. A.

ABSTRACT: This study explores culturally responsive curriculum and pedagogy in the Commonwealth of the Northern Mariana Islands (CNMI). In particular, it examines the ways in which teachers and administrators view curriculum and pedagogy within the multiple and overlapping cultural contexts that the CNMI inhabits. By using an open-ended questionnaire, onsite interviews, and an exhaustive recruitment strategy, the study afforded every middle and high school social studies teacher in the CNMI an opportunity to participate in this study. The findings reveal a wide range of attention to cultural responsiveness, and numerous successes and challenges within middle and high schools.

KEYWORDS: culturally responsive pedagogy, Commonwealth of the Northern Mariana Islands, social studies, teacher perspectives, colonialism

Geographical, Historical, and Educational Background Culturally Responsive Curriculum and Pedagogy

Research Method

Findings

Discussion

Conclusion

References

Author Contact

Appendix A: Questionnaire

Appendix B: Interview Questions

Given the colonial relationship between the U.S. mainland and U.S. territories, including the creation of separate and subordinate systems that are owned by, but not a part of, the United States, the extent to which education in colonial contexts is responsive to its citizens' cultural and historical backgrounds has profound implications for preparing students for college, career, and civic life. As part of the empirical turn toward decolonizing practices, critical pragmatism, and culturally responsive education, this study explores culturally responsive curriculum and pedagogy in the Commonwealth of the Northern Mariana Islands (CNMI) and seeks to add to a growing body of literature that will lead to policy changes and determinations that honor and empower indigeneity within multiple and overlapping contexts. 


\section{Geographical, Historical, and Educational Background}

The Commonwealth of the Northern Mariana Islands (CNMI) is located 1,500 miles east of the Philippines, 1,200 miles southeast of Japan, and includes 20 islands spread along a 500-mile arc containing 184 square miles of land distributed among 264,000 square miles of ocean. Saipan is the largest (47 square miles) and most populated island with 48,220 residents (90\% of the CNMI) (Quimby, 2013) while Tinian $(3,136)$ and Rota $(2,527)$ are the other two inhabited islands among the CNMI. Recent DNA research suggests that Saipan's indigenous population arrived 4,000 years ago from Island Southeast Asia and developed in isolation (Misco, in press; Vilar et al., 2013).

In 1521, the Spanish colonized these islands, named them after Queen Mariana of Austria, and, through disease as well as war, the native population was reduced from 50,000-100,000 to 1,000. The Spanish forcibly relocated the surviving native population to other islands (Vilar et al., 2013), and only in 1816 did Chamorros begin to repopulate Saipan (de los Santos, 2010). Chamorros and Carolinians attempted to maintain their indigenous identities, languages, and cultures, while "acculturating to Spanish Catholicism, urban settlement, wage labour, and Westernized life styles" (Quimby, 2013, p. 465). As of 2010, the CNMI had 53,883 residents, including Filipino $(19,017)$, Chamorro $(12,902)$, Chinese $(3,659)$, Carolinian $(2,461)$, and "other Pacific Islanders" $(3,437)$. Korean $(2,253)$, "other Asian" $(1,979)$, "other ethnic origin" $(1,343)$ and "two or more ethnic origins" $(6,832)$ constitute the remainder of the population (Misco, in press; U.S. Census Bureau, 2010).

After the Spanish-American War (1898), Spain sold Saipan, as well as other islands, to Germany who held and occupied these islands until 1914, when Japan declared war, invaded, and occupied the present-day CNMI. After WWI, the League of Nations assigned Saipan, as well as all the Mariana Islands, to Japan to be held in trust (de los Santos, 2010). Following the victory in the eponymous Battle of Saipan during World War II, the United States assumed control of the islands that would become the Commonwealth of the Northern Mariana Islands (CNMI), the Federal States of Micronesia, the Republic of the Marshall Islands, and the Republic of Palau. These islands, in addition to Guam, constitute the geographic construct of Micronesia (Heine, 2002). In an agreement with the United Nations, the United States held these islands under the Trust Territory of the Pacific Islands, with the understanding that the islands would eventually become self-determining and that the United Sates was "obligated to prepare these entities for self-government" (Heine, 2002, p. 2). The trusteeship disbanded in 1986, eight years after the CNMI voted for, and gained, commonwealth status as an unincorporated territory of the United States. As such, the CNMI has its own government and constitution, as well as local control of wage, tax, and immigration policies. Yet, similar to other territories, it is owned by, but is not a part of, the United States, and thus it currently inhabits a colonial space (Misco, in press). 
Since the end of WWII, education in the Mariana Islands "has been prodded and coaxed toward a general U.S. model, with varying degrees of success" (de los Santos, 2010, p. 131), yet any progression toward a "U.S. model" contains dubious motivations and consequences. For example, Gay (2000) has argued that "decontextualized teaching and learning from the ethnicities and cultures of students minimizes the chances that their achievement potential will ever be realized" (p. 23). Moreover, mainstream schools are grafting onto a data-driven model that presents risks to the potential extermination of indigeneity, in terms of identity, language, and cultural practices (Huaman, 2013). Instead, a need exists for ethnosensitivity and culturally relevant content (Gay, 2010).

Although residents of the Mariana Islands voted overwhelmingly to become a Commonwealth of the United States (1978), they were encouraged to become part of the "American world" without a proper provision of the tools needed to participate with substantive efficacy (de los Santos, 2010). In short, those of the $\mathrm{CNMI}$ must ask whether they are deriving the education they and their children truly need from this system. Without participation on the part of those directly concerned, education in the CNMI "will never be made to approach its potential" (de los Santos, 2010, p. 131). Similarly necessary is the empowerment and encouragement for all Micronesians to "take control of their school curricula and the transference of their culture to their children" (O'Neill \& Spennemann, 2008, p. 215).

As of 2008 , the CNMI public K-12 budget was $\$ 69,017,086$, and $70 \%$ of all students graduated from high school (WestEd, 2018). Saipan has seven elementary schools, five middle schools, and four high schools, while Tinian and Rota each has an elementary school and a school serving grades 7-12. The mission of the CNMI Public School System is:

[To] offer equitable educational opportunities for all students by providing optimum curriculum, instruction, community service, and work experience in academic and career-technical education so as to promote their development as productive and contributing members of the Commonwealth and the global world. (CNMI Public Schools, 2018)

Given the rich diversity of ethnicities and cultural backgrounds within and across the three islands of Rota, Saipan, and Tinian, this study eschews any dualistic or oversimplified attempts at describing culture when there are cultures and subcultures interacting within schools (Fraise \& Brooks, 2015).

\section{Culturally Responsive Curriculum and Pedagogy}

The CNMI is situated within a colonial construct "located, bounded, defined, and described by a series of different colonial regimes whose efforts were selfserving and exploitative" (Clark, 2003, p. 155). Those within the CNMI face a long history of colonialism and powerful cultural influences including school curricula, expatriate teachers not versed in local culture, and a potential lack of culturally 
relevant teaching (O'Neill \& Spennemann, 2008). Culturally responsive pedagogy, teaching, and curriculum calls for a multidimensionality of curriculum, classroom climate, and teacher-student interactions. It should be both transformative and emancipatory, as it "releases the intellect of students of color from the constraining manacles of mainstream canons of knowledge and ways of knowing" (Gay, 2010, p. 37). Because textbooks and homogeneous standards often fail to address culturally relevant content and concepts, too often subject matter is taught as "culturally unfamiliar" (Menchaca, 2001, p. 18). Curriculum should not be static, but rather dynamic and imbued with culture. It is a "living, breathing organism through which we create our visions of our pasts, presents, and futures" (Ladson-Billings \& Brown, 2008, p. 169), yet many of the studies that have explored culturally responsive teaching have taken place in homogenous contexts. Teacher preparation programs need to be informed by, and model, practices that are responsive to all learners across multiple cultural backgrounds (Herrera, Holmes, \& Kavimandan, 2012). One such context, the CNMI, is a research site that houses a rich and understudied diversity that offers transferability to inform practice in other contexts.

The concept of Culturally Responsive Curriculum provides a lens for highlighting the cultural, historical, and social contexts in which people inhabit and engage in education (Marsico, Dazzani, Ristum, \& Bastos, 2015). This kind of curriculum has legitimate salience for all students (Sleeter \& Cornbleth, 2011), given that minority populations nationwide are the numeric majority in Hawaii (77.3\%), California (59.9\%), New Mexico, (59.5\%), and Texas (54.7\%) (Banks, 2016). In the CNMI, minority populations (by the U.S. mainland standards) constitute $98 \%$ of the population. As seen through these states and other contexts, people live in socially constructed subcultures and continually negotiate the "global flow" of knowledge and the "transnational traffic in ideas" (Anderson-Levitt, 2012, p. 18). Native ethnicity and culture ultimately anchor some behaviors, in particular expressive behaviors such as writing, learning, speaking, and teaching (Gay, 2000), which can contain significant gaps with regard to the formal curriculum.

Culturally Responsive Curriculum conceptually seeks to create connections between home and school while also meeting the expectations of the district and state through utilizing the backgrounds, knowledges, and experiences of students to inform teachers' decision-making (Coffey, 2008). Whereas Culturally Responsive Teaching is sometimes treated simplistically, in trivialized, essentializing, or celebratory ways, deeper versions of Culturally Responsive Pedagogy focus on context and aim towards equity and justice (Sleeter, 2011). It is the latter of these in which Culturally Responsive Curriculum fits, with attention paid to students' thinking, learning, and defining themselves in relation to their culture.

If students have worldviews that differ from the Western or mainland canonical learning materials, then they are "more likely to find themselves in conflict with the curriculum being taught" (Jones, Pang, \& Rodriguez, 2001, p. 36). Because personal and cultural knowledge contains the "concepts, explanations, and interpretations that students derive from personal experiences in their homes, 
families, and community cultures" (Banks, 2016, p. 183), school and societal knowledge in the CNMI is quite salient, given that much of the school knowledge is transplanted from the mainland United States. Additionally, a curriculum that is culturally irrelevant and lacks multicultural resources contributes to notions of citizenship (Ramirez \& Jaffee, 2016). Moreover, the culture of school in the form of curriculum and its enactment may not act in a synchronized way with the culture of ethnic groups (Gay, 2000).

Because Culturally Responsive Teaching acknowledges the legitimacy of cultures among different ethnic groups and "builds bridges of meaningfulness between home and school" (Gay, 2000, p. 29) it is worth asking whether a bridge should be built for curriculum. Teachers are to be "skillful cultural mediators" (Sleeter \& Cornbleth, 2011, p. 4) who help make meaningful connections between education and student experiences as culturally harmonious and congruent (Jones, Pang, \& Rodriguez, 2001; Sleeter, 2011). Although many teachers are interested in culturally relevant pedagogies, they often struggle to realize their potentialities and full enactment (Zenkov et al., 2013). Moreover, conversations about culturally relevant teaching are too often confined to academic circles as opposed to informing practitioners (Boutte, Kelly-Jackson, \& Johnson, 2010). Thus, the research question guiding this study seeks to understand the extent to which teaching, learning, and curriculum in the CNMI provides culturally responsive educational experiences. The more than 500 years of Spanish, German, Japanese, and U.S colonial imposition, as well as continual pressures and mandates as a site of U.S. public education within a colonial context, provide the rationale and justification for this research question.

\section{Research Method}

During this study, I was known to respondents as an outsider. As a researcher, I recognize my positionality as a Westerner who has a perspective informed by life within the mainland United States. Yet, the sum total of my international experiences and research in international contexts has allowed me to be conscious of that limitation and assume a transnational, cosmopolitan, and postcolonial perspective. The dearth of educational research in the CNMI, the importance of the CNMI within the Pacific and global community, and the importance of understanding the next generation of multicultural democratic citizens within a U.S. colonial context provided the primary justification for this work. By drawing on an established network of contacts within the CNMI public school system established through initial visits to educational sites, I embarked on a qualitative case study that explored narrative experiences as located within a post-positivistic paradigm of multiple and overlapping contexts (Miles \& Huberman, 1994; LeCompte \& Schensul, 1999).

The type of sample I sought to achieve was non-random, and it endeavored to include all informants of the target population. In accordance with the CNMl's Department of Education instructions, I contacted each school principal through 
email to inform them about the study. I then emailed all social studies teachers and invited them to participate in the study. I decided to focus this research on social studies teachers given the rich potentialities of culturally responsive teaching and learning with regard to culture, ethnicity, race, class, gender, history, and geography. I sent an invitation to a web-based questionnaire to each middle school and high school social studies teacher in CNMI, grades 6-12 $(n=33)$. In order to maximize the response rate to the questionnaire, I employed a variety of strategies known to yield greater responses, which included preliminary notification by emailing respondents in advance (Yammarino, Skinner \& Childers, 1991), a relatively short and straightforward questionnaire format (Cole, Palmer, \& Schwanz, 1997), and university sponsorship (Fox, Crask, \& Kim, 1988). I offered each respondent a $\$ 10$ Amazon gift card as an incentive to participate.

As a result of this exhaustive recruitment strategy, 12 teacher participants, as well as two administrators, (36\%) responded. I extended invitations to the 14 total respondents to meet for a one-hour interview, within the CNMI, to further explore questionnaire topics and questions from the questionnaire. For this phase of the study, participants were offered a \$25 Amazon gift card incentive. Six teachers and administrators from middle and high schools agreed to be interviewed.

This study employed qualitative methods primarily because they are wellsuited for addressing research problems concerning norms, structures, conditions, and processes (Glaser \& Strauss, 1967), features at the heart of this study's scope and aim. Moreover, these questions contain normative elements and assume a constructivist ontology, which undergirds qualitative methods and asserts that there is not one reality, but rather multiple interpretations and renderings of the world (Merriam, 2001). Rather than applying analytical tools a priori, analysis involved data induction to form theoretical categories and tentative relationships (Lincoln \& Guba, 1985). For example, I recursively and inductively examined all of the teacher and administrator interviews to arrive at emergent themes. By employing an inductive-generative-constructive approach, I sought to understand relationships of data (i.e., generate hypotheses) through initial observation, refinement, and comparison to emergent category coding, whereby collection and processing of data was simultaneous (Goetz \& LeCompte, 1984; Lincoln \& Guba, 1985). Tentative typologies structured data reduction and organization by recurring themes that fit within the established research questions, while attempting to retain conceptuality and not dilute thick description into thin description (Steiner-Khamsi, Torney-Purta, \& Schwille, 2002).

I reconstructed data through the process of analytic induction (Goetz \& LeCompte, 1984) whereby I scanned data for categories of phenomena and relationships among categories. I then developed working typologies based on multiple visits to the $\mathrm{CNMI}$, which resulted in modification and refinement due to subsequent cases. Analytic induction seeks comprehensive rather than probabilistic explanations, whereby all phenomena are explained, not only some distribution of cases (Goetz \& LeCompte, 1984). 


\section{Findings}

The findings are organized into three sections. I first address the awareness, rationale, and need for addressing culture within curriculum and pedagogy. I then explore the role of middle school teachers, all former elementary school teachers, in paying attention to culturally responsive teaching and learning. Finally, I discuss the specific challenges to culturally responsive curriculum and pedagogy as found within high schools and the promise of one administrator's attempts to reconcile cultural and dominant canons of knowledge and ways of knowing.

\section{Efforts to Promote Cultural Responsiveness}

Questionnaire and interview data suggested that a wide range of efforts are in place to develop and support culturally responsive curriculum and pedagogy in $\mathrm{CNMI}$ schools. For many respondents, especially those teaching in middle schools, culture helps bring about meaning, and it is essential connective tissue for learning content. For example, Victor, a Chamorro middle school teacher from Guam, stated, "[l] always reference local matters or customs to compare an ancient matter or custom." Clarence, a Caucasian high school teacher from the mainland, directed "students to actual events that happened in history." He liked to include "local perceptions and opinions in his lessons" and encouraged "students to form their own opinions and write about them in reflections and assignments." Taitasi, a Filipino-Palauan-Yapese-Caucasian middle school teacher gave "kids the knowledge and awareness of other cultures and ethnic backgrounds." She saw "the CNMI as an extremely culturally diverse melting pot in which people from all over the world and the Pacific have come to live." Teaching about cultural diversity, she said, "helps students respect others and have a better understanding of the cultures of others which makes students more compassionate and understanding members of the community."

Yet some teachers found that their students had not developed meaningful connections to their culture in early grades and therefore a substantive approach needed to be taken. For example, Taitasi reported that students had little or no idea of the history of the island and the surrounding islands. Taitasi suggested that the majority of her curriculum centered upon local culture and context, with the first four months spent learning about the culture of the Marianas from migration from Southeast Asia to the present. Her classes then looked to Micronesian, Melanesian, and Polynesian cultures, but they continuously made comparisons and connections with and to the local culture.

Middle school teacher responses coalesced around the theme of meaning as well. We can think of meaning in the pragmatic Deweyan sense of ideas or connections and relations that people have to other ideas and people (1933). In 
this way, Kamia, a Chamorro middle school teacher from Saipan, indicated that they broached issues that the CNMI faced so that students could realize that "studying the past can help us understand the present." Naile, a Chamorro middle school teacher, reported that she consistently advanced "real life examples that are island- and student-specific," while Malaya, a Filipino middle school teacher, was persistently sensitive to a wide variety of learners whose various cultures were well represented in student demographics. For example, some topics were deemed controversial, including Scarborough Shoal (one of the territorial disputes in the South China Sea) as well as the current buildup of island and military bases around Saipan. Camarin, a Chamorro middle school teacher, focused on making social studies coursework "meaningful for them." She stated, "I always look for connections and I take into consideration the students, including Pacific history where we always talk about how it came to be, who founded the NMI [Northern Mariana Islands], and how we came to be." Because the CNMI has such a diverse ethnic population, including recent immigrant groups from the outer islands of Chuuk, she looked to each student's cultural background, including Palau and Micronesia, because many students were not aware of these unique histories. She also tried to include children from China and asked them to share from their perspectives by posing the question, "What does that mean to you?" Camarin found it easy to relate concepts of import/export, government assistance, and agriculture because it was easy to relate to any location and cultural background. For example, she asked, "Palau, CNMI, where would you find this produced? Is it exported?" Camarin further indicated that her middle school faculty had gradelevel meetings where they discussed what they were teaching and determined how to integrate all subjects and reach all students in a holistic vertical and horizontal curriculum. For example, when they discussed the economy and resources, she said:

We always try to do research in language arts, and graphing in math, and the science aspects to it. One time we tried to all teach about global warming as the four of us doing that with student backgrounds being taken into account.

Likewise, Flores, a Chamorro middle school teacher from Saipan, always started planning her classes with her diverse students in mind, and these included Chinese, Chuukese, Caucasians, Russians, and Koreans, as well as Chamorro and Filipino students.

Some teachers reported challenges to making meaningful connections, including parental participation, poverty, and lack of knowledge about salient issues affecting the CNMI. Flores, for example, found it challenging to communicate with parents and make connections to culture when there were so many different cultures represented in her classroom. In addition, she felt that the common core and mainland curricular standards were "ok," but she also noted the large number of students who "haven't even traveled to other parts of the island and have no technology." Given high poverty and students as the "ones teaching the parents," she argued, "kids have to be ready and if they want to go abroad and this is their practice now." Rather than rejecting the mainland curricular influences 
wholesale, she instead redoubled her efforts to forge connections between the U.S. mainland and the CNMI, especially in light of the connections that tourism, garment factories, the global economy, and unemployment hold. According to Flores, many children "didn't even know about Oceania and Guam" and "all they know is the CNMI;" in addition, they "lacked knowledge about welfare, poverty, budget issues, and understanding how things work." Many of Flores' students lived in poverty, most relied upon free and reduced lunch, and parents typically did not attend school meetings. Flores observed how she learned about her students:

[In] home visits, we know where they are coming from what they have and don't have. It's a real challenge with many broken families... a lot of issues. Kids come to school and that's where they can escape and where they are welcomed. Sometimes we have to go beyond and provide resources, computer time, etc. Our district is doing a good job, I think.

Teachers such as Flores demonstrated the potential of CNMI teachers to enlist tremendous efforts to build culturally responsive support networks and pathways for meaningful education.

\section{Middle School Teachers}

All current middle school teachers within the CNMI were previously elementary teachers, prior to a change in certification parameters that permitted an adjustment in certification related to grade bands. As a result, these teachers reported to know the children and focus more on children than content, as compared to secondary teachers. Respondents pointed to the elementary training and prior teaching experiences as positioning them well to provide guidance and support for students. They noted that whereas in the high schools teachers were teaching "kids much more like adults," in middle school much more attention was given to children's home lives.

As Gregorio put it, "There is more humanity in middle school. Just depends on the teacher. If you care a lot, you will find ways." Gregorio went on to note that the possibilities of culturally responsive curriculum and instruction in high schools ultimately depended on the teacher. He posited that if they too were well prepared and passionate about making content meaningful and making connections with cultural backgrounds, then they could be quite successful at the high school level. If so, high school students could then realize more relations and connections, including the history of changes to the CNMI since the Spanish first came in 1521.

Bendision, a Chamorro administrator with 26 years teaching experience, also critiqued "traditional" teachers in high school in comparison with middle school teachers:

[The traditional teachers] don't want to work hard. Now we try to work with integration, especially at the high school level. They will not come out and do this, but in the middle school they do a better job. There are newer 
teachers, doing a better job of engaging kids, and making all the connections.

His vision of culturally responsive curriculum and pedagogy also focused on connections, doing research into cultural history and exploring voting rights, and positioning students to develop a global perspective. He reported that some high school teachers are just not "reaching out, sparking, or touching the kids with engaging activities and learning." Whereas collaboration among teachers who built upon local and cultural perspectives was more common in middle schools, at the high school level he felt teachers had a lot of expertise but there needed to be more connections within and among lesson plans, standards, and children.

In middle schools the focus was centered on the children and connection with parents. Time and attention came from individual teacher motivation as well as administrators who realized its importance. Teachers were expected to spend more time and attention on the home context, languages, siblings, and issues families faced. Bendision noted the challenges of many children as the reason for his expectation for the teachers' attention:

[Many children] still work with candle lights because they can't pay bills. They [teachers] need to be sensitive to kids and understand students! You need to sit down and fully understand the kids and their home life. What are you going to do to make that happen?

To address the problem, Bendision focused on after-school tutoring and frequently sent his faculty articles that provided innovative ideas for how to build connections with parents and families. In short, although dependent upon the teacher and the administrator, generative and pervasive efforts were made to aim at realizing a culturally responsive curriculum and pedagogy at the middle school level.

\section{Challenges in High Schools}

Respondents suggested that the focus on culturally responsive curriculum and pedagogy rarely extended to the high school level. Gregorio, a Chamorro vice principal, indicated that high schools too often had classrooms of teachers who were squarely focused on content and pontificating rather than building connections and designing relevant curriculum for children. Described as "one dimensional in terms of teaching," he noted that although there was SIOP (Sheltered Instruction Observation Protocol) for differentiated instruction, many of the teachers had been teaching in the same school for a long time and were therefore "rooted" and "unwilling to change." He often failed to see evidence of teachers considering what children might need, and he often did not see lesson plans that demonstrated thoughtfulness in terms of culture. Moreover, many lessons also missed a sense of scope and sequence in what they addressed. As a result, individual lessons were too often not only connected to the child but they also lacked meaningful connections to subsequent topics. He reported that a large number of teachers failed to activate prior knowledge and instead they engaged in 
direct instruction whereby teachers approached students with the attitude of "let me tell you and [then] let me test you."

Gregorio noted exceptions to this sort of instruction, including some classes that were heavily discussion-oriented and student-centered. However, other than a few classes of this kind, he found the primary focus to be on declarative factbased content knowledge whereby "even the student-centered class doesn't do culturally relevant teaching...more [focusing on] the canon." Although it may be engaging, he suggested, it lacks cultural relevance. He also noted that math teachers, who used a narrative approach to teaching, were more cognizant of developing a culturally responsive curriculum. One example he cited included building canoes using measurement at the elementary level. As an administrator he pointed to the goal at the high school level where students were supposed to learn about their own identities but given a recent district self-assessment in which multiculturalism and cultural relevance was measured within the schools, this was one of the weakest identified areas.

Gregorio also voiced larger concerns about identity concerns within the CNMI given its diverse cultures and history. He felt that in many ways the CNMI did not have a good sense of its own identity and therefore questioned how citizens could have a culturally relevant curriculum if that was not in place. By comparison, he felt Guam had a much better sense of their identity, primarily Chamorroness. In Guam, suggested Gregorio, there was an "urgency to connect with cultural mores and values" that was not felt in Saipan. Whereas Guam might have the infusion of "imagination and their history which is even connected to the Spanish," forming a redefined version of what Chamorro culture is, he continued, "At least they are doing something to preserve culture. Here there is no urgency." The cultural values that focused on reciprocity and family connections were still valued in Saipan, as well as more traditional values that were still practiced. Yet, their $4^{\text {th }}$ of July parade, although ostensibly arranged to highlight culture, did not include Chamorro people. Gregorio asked, "Is that because Chamorro is the dominant culture here? Perhaps that's what it is. We are primarily tourist destinations. We perform Polynesian entertainment, but we are not in Polynesia."

The perennial tension between Western or mainland curriculum and culturally relevant curriculum was, Gregorio contended, "often a dichotomous relationship." He used to believe that it was either/or, in the sense that if he allowed for the dominant canon then he would be unable to value his own culture. He bargained initially believing that the dominant Western canon and culture was what was needed to succeed in a globalized world. But now he thought otherwise, saying, "I think we can have both." In order to reconcile the dialectical tension, Gregorio worked to value and enhance cultural identity within the framework of the Western curriculum. Through this approach he suggested that people could "bring value-added by understanding your identity." This reconciliation undergirded motivation to develop new frameworks for lesson planning, employment of narrative approaches, and more focused use of critical questioning strategies that could draw on culture but also responded to common core and Western curricula. $\mathrm{He}$ added that this approach "needs to be the focal point and assessments. The 
standards are the staple, but so is a culturally responsive framework." Gregorio was by far the most progressive thinker among those who were culturally responsive educators interviewed for this study.

\section{Discussion}

As noted in the findings, questionnaire and interview data revealed three main themes concerning culturally relevant curriculum and pedagogy in the CNMI. First, respondents suggested that the efforts to promote cultural responsiveness largely hinged on creating meaningful connections for students as described by Jones, Pang, and Rodriguez (2001) and Sleeter (2011). Questionnaire data suggested a multidimensionality of curriculum as respondents indicated their efforts to create connections between home and school while also meeting the expectations of the district and state through utilizing backgrounds, knowledges, and experiences of students to inform teacher decision-making (Coffey, 2008). Most respondents remarked on making curriculum meaningful, primarily through connections, including the student in the prescribed content, local history, and current issues. Given that a variety of teachers were frustrated with how little students knew at the start of middle school about Oceania, Guam, and anything other than the CNMI, respondents remarked on how connections of context within the region and to the mainland are essential. Teachers made note of avoiding instruction in the social studies in ways that are "culturally unfamiliar" (Menchaca, 2001, p. 18) and rather, in particular within the middle schools, acting as "skillful cultural mediators" (Sleeter \& Cornbleth, 2011, p. 4).

Yet, numerous challenges existed, including lack of earlier attention to cultural references and salient issues at the elementary school level, as well as a paucity of parent involvement and pervasive poverty. Teachers and administrators who were keen to ensure that culturally responsive teaching and learning were working to surmount these challenges, through home visits, inservice enrichment in the form of readings, and redoubled efforts with reimagining curriculum.

Because all middle school teachers were former elementary teachers, they appeared to have a more substantive focus on students rather than content. Their experiences and background had prepared them to take ownership of their schools and the extension of their culture to their children (O'Neill \& Spennemann, 2008). The extent to which this happened very much hinged on the motivation and interest of the administrator and teacher. The internal tension of experience is noteworthy here, given the choice of teachers to either leverage their knowledge of the diverse cultures within the CNMI within their teaching or maintain habitual curricular frameworks and modes of learning. In short, the teacher was the primary lever for creating culturally responsive curriculum and pedagogy.

Respondents suggested that it was within CNMI high schools that the immense curricular power of the teacher might lead to underwhelming cultural responsiveness. Respondents remarked that it was not only an overemphasis on 
mainstream canonical content, but also an unwillingness to change either content or pedagogy in light of local cultural particularities. Reconsidering content knowledge, in light of the wide-range of different canonical knowledges available for teachers to leverage and deploy (Banks, 1993), is something that one administrator uniquely grappled with as he tried to reconcile the forces of the mainland and the indigeneity of the CNMI. In particular, his dialectical resolution of housing cultural knowledge and practices within a larger frame of mainland canonical efforts may be a seemingly potent way of proceeding.

The theoretical call for reclaiming an indigenous epistemology (Rizvi, Lingard, \& Lavia, 2006; Lavia \& Mahlomaholo, 2012; Urrieta, 2004) seems less of a priority in the CNMI than ensuring that students and community members are connected to their history and culture. As other respondents noted, it is the "lovehate relationship" that citizens of the CNMI have with the mainland that reveals the ongoing quest for beneficially resolving a colonial past and present, as well as mainland mandates coinciding with the preservation of local cultural values and practices.

\section{Conclusion}

In short, the extent to which students enjoy a culturally responsive classroom, in terms of curriculum, instruction, and pedagogy, very much depends upon the teacher. Those who are passionate and connect culture are able to better "release the intellect of students of color from the constraining manacles of mainstream canons of knowledge and ways of knowing" (Gay, 2010, p. 37). Given that middle school teachers are better equipped to do so within the course topics of the middle school, the experience of teachers with a focus more on students than content discipline, and a more personal experience with local culture, how might these successes be leveraged for widespread adoption? High schools would seem to be the place to start, perhaps with inservice trainings and other enrichments where the deeper versions of culturally responsive teaching, pedagogy, and curriculum, with a focus on context and aim towards equity and justice (Sleeter, 2011), are more rare. There, the culture of school in the form of curriculum and its enactment may not act in a synchronized way with the culture of ethnic groups (Gay, 2000). Culturally responsive curriculum, pedagogy, and teaching is "tailor-made" and contextualized for particular students and student groups (Sleeter \& Cornbleth, 2011, p. 4). Given the past, and current, colonial and postcolonial relationship the CNMI has with the United States, there exists a moral imperative to do so.

I propose to work toward resolving this problem not by recommending future research or pushing external hortatory initiatives as an outsider but rather by developing a new iteration of National Council for the Social Studies curriculum standards and performance expectations for the unique context of the CNMI. Through the methods of curriculum deliberation (Misco, 2007), new curricular 
frameworks designed by and for stakeholders in the CNMI can help codify and operationalize culturally relevant curriculum and pedagogy district-wide.

\section{References}

Anderson-Levitt, K. M. (2012). Introduction. Anthropologies and ethnographies of education worldwide. In K. M. Anderson-Levitt (Ed.), Anthropologies of education: A global guide to ethnographic studies of learning and schooling (pp. 1-28). New York, NY: Berghahn.

Banks, J. A. (1993). The canon debate, knowledge construction, and multicultural education. Educational Researcher, 22(5), 4-14.

Banks, J. A. (2016). Cultural diversity and education. New York, NY: Routledge.

Boutte, G., Kelly-Jackson, C., \& Johnson, G. L. (2010). Culturally relevant teaching in science classrooms: Addressing academic achievement, cultural competence, and critical consciousness. International Journal of Multicultural Education, 12(2), 1-20.

Clark, G. (2003). Dumont d'Urville's oceania. The Journal of Pacific History, 38(2), 155-161.

de los Santos, R. (2010). A history of the Northern Marianas educational system. San Bernardino, CA: Xlibris.

Coffey, H. (2008). Culturally relevant teaching. Retrieved from www.learnnc.org/lp/pages/4474

Cole, C., Palmer, R., \& Schwanz, D. (1997). Improving the mail return rates of SASS surveys: A review of the literature. Suitland, MD: Bureau of the Census. Retrieved from ERIC database. (ED 416248)

CNMI Public Schools, (2018). Public School System of the Northern Mariana Islands. Retrieved from https://www.cnmipss.org

Dewey, J. (1933). How we think. Boston, MA: D.C. Heath \& Co.

Fox, R., Crask, M., \& Kim, J. (1988). Mail survey response rate: A meta-analysis of selected techniques for inducing response. Public Opinion Quarterly, 52(4), 467-491.

Fraise, N. J., \& Brooks, J. S. (2015). Toward a theory of culturally relevant leadership for school-community culture. International Journal of Multicultural Education, 17(1), 6-21.

Gay, G. (2000). Culturally responsive teaching. New York, NY: Teachers College Press.

Gay, G. (2010). Culturally responsive teaching (2 ${ }^{\text {nd }}$ ed.). New York, NY: Teachers College Press. 
Glaser, B. G., \& Strauss, A. L. (1967). The discovery of grounded theory. Chicago, IL: Aldine.

Goetz, J. P., \& LeCompte, M. D. (1984). Ethnography and qualitative design in educational research. Orlando, FL: Academic Press.

Heine, H. C. (2002). Culturally responsive schools for Micronesian immigrant students. Washington, D.C.: Department of Education. Retrieved from ERIC Database. (ED 476109)

Herrera, S. G., Holmes, M. A., \& Kavimandan, S. K. (2012). Bringing theory to life: Strategies that make culturally responsive pedagogy a reality in diverse secondary classrooms. International Journal of Multicultural Education, 14(3), 1-19.

Huaman, E. A. S. (2013). Conversations on Indigenous education, progress, and social justice in Peru (Conversaciones sobre educación indígena, progreso, y justicia social en el Perú). International Journal of Multicultural Education, 15(3), 10-25.

Jones, E. B., Pang, V. O., \& Rodriguez, J. L. (2001). Social studies in the elementary classroom: Culture matters. Theory into Practice, 40(1), 35-41.

Ladson-Billings, G., \& Brown, K. (2008). Curriculum and cultural diversity. In F. M. Connelly, M. F. He, \& J. Phillion (Eds.), The SAGE handbook of curriculum and instruction (pp. 153-175). Thousand Oaks, CA: SAGE.

Lavia, J., \& Mahlomaholo, S. (2012). Imagining the postcolonial. In J. Lavia \& S. Mahlomaholo (Eds.), Culture, education, and community: Expressions of the postcolonial imagination (pp. 1-14). New York, NY: Palgrave Macmillan.

LeCompte, M. D., \& Schensul, J. J. (1999). Designing and conducting ethnographic research. Walnut Creek, CA: AltaMira.

Lincoln, Y. S., \& Guba, E. G. (1985). Naturalistic inquiry. Beverly Hills, CA: Sage.

Marsico, G., Dazzani, V., Ristum, M., \& de Sousa Bastos, A. C. (Eds.). (2015). Educational contexts and borders through a cultural lens: Looking inside, viewing outside. New York, NY: Springer.

Menchaca, V. D. (2001). Providing a culturally relevant curriculum for Hispanic children. Multicultural Education, 8(3), 18-20.

Merriam, S. B. (2001). Qualitative research and case study applications in education. San Francisco, CA: Jossey-Bass.

Miles, M. B., \& Huberman, A. M. (1994). Qualitative data analysis. Thousand Oaks, CA: Sage.

Misco, T. (in press). "It is definitely not the priority": A postcolonial inquiry of social studies education in the Commonwealth of the Northern Mariana Islands. Journal of Social Studies Research. 
Misco, T. (2007). Using deliberation to address controversial issues: Developing Holocaust education curriculum for Latvian schools. International Journal of Education Policy and Leadership, 2(8), 1-12.

O'Neill, J. G., \& Spennemann, D. H. R. (2008). Education and cultural change: A view from Micronesia. International Journal of Educational Development, 26(2), 206-217.

Quimby, F. (2013). Americanised, decolonised, globalised, and federalized: The Northern Mariana Islands since 1978. The Journal of Pacific History, 48(4), 464-483.

Ramirez, P. C., \& Jaffee, A. T. (2016). Culturally responsive active citizenship education for newcomer students: A cross-state case study of two teachers in Arizona and New York. International Journal of Multicultural Education, 18(1), 45-67.

Rizvi, F., Lingard, B., \& Lavia, J. (2006). Postcolonialism and education: Negotiating a contested terrain. Pedagogy, Culture \& Society, 14(3), 249-262.

Sleeter, C. E., \& Cornbleth, C. (2011). Introduction. In C. E. Sleeter \& C. Cornbleth (Eds.), Teaching with vision: Culturally responsive teaching in standardsbased classrooms (pp. 1-10). New York, NY: Teachers College Press.

Sleeter, C. E. (2011). An agenda to strengthen culturally responsive pedagogy. English Teaching: Practice and Critique, 10(2), 7-23.

Steiner-Khamsi, G., Torney-Purta, J., \& Schwille, J. (2002). Introduction: Issues and insights in cross-national analysis of qualitative studies. In G. SteinerKhamsi, J. Torney-Purta, \& J. Schwille (Eds.), New paradigms and recurring paradoxes in education for citizenship: An international comparison (pp. 136). London: Elsevier.

Urrieta, L. (2004). Dis-connections in "American" citizenship and the post/neocolonial: People of Mexican descent and whitestream pedagogy and curriculum. Theory and Research in Social Education, 32(4), 433-458.

U.S. Census Bureau, (2010). Commonwealth of the Northern Mariana Islands. Retrieved from http://www.census.gov/population/www/cen2010 /island_area/cnmi.html

Vilar, M. G., Chan, C. W., Santos, D. R., Lynch, D., Spathis, R., Garruto, R. M., \& Lum, J. K. (2013). The origins and genetic distinctiveness of the Chamorros of the Marianas Islands: An mtDNA perspective. American Journal of Human Biology, 25, 116-122.

WestEd, (2018). Pacific islands climate education partnership. Retrieved from http://pcep.wested.org/content_items/389065.html

Yammarino, F. J., Skinner, S. J., \& Childers, T. L. (1991). Understanding mail survey response behavior: A meta-analysis. Public Opinion Quarterly, 55(4), 613-639. 
Zenkov, K., Pellegrino, A., Harmon, J., Ewaida, M., Bell, A., Lynch, M., \& Sell, C. (2013). Picturing culturally relevant literacy practices: Using photography to see how literacy pedagogies matter to urban youth. International Journal of Multicultural Education, 15(2), 1-20.

\section{Author Contact}

Thomas Misco: miscotj@miamioh.edu Miami University, 301G McGuffey Hall, Oxford, OH 45056 U. S. A.

\section{Appendix A: Questionnaire}

Dear Participant, The purpose of this research study is to understand the extent to which social studies curriculum and curricular ideas are culturally responsive to students in the CNMI. Taking part in this research study is completely voluntary. You may choose not to take part at all. If you decide to participate in this study, you may stop participating at any time. If you decide not to be in this study, or if you stop participating at any time, you will not be penalized or lose any benefits for which you otherwise qualify. Those who fully complete the survey will receive an electronic $\$ 10$ Amazon gift card. If you agree to take part in this study, your survey responses will take approximately 20 minutes to complete. At the end of the survey, you will be asked if you are willing to participate in a one-hour follow-up interview for an additional $\$ 25$ gift card. There will be no penalty if you chose to take the online survey, but then indicate that you are not willing to participate in a follow-up interview. There are no foreseeable risks in participating in this study all responses will be confidentially maintained and any reporting from the study for use in articles, books, and presentations will employ non-identifying data. Although every effort will be made to ensure confidentiality of your responses to this survey, all internet-based communication is subject to the remote likelihood of tampering from an outside source. Your responses will be recorded under a code and not your name, and every effort will be made to ensure confidentiality. Your responses will be kept in a locked cabinet and/or on a password protected computer. When publishing or communicating results, no personal identifiers will be used. Your answers will be destroyed once the study is published. By checking the "I consent" box below, you will have indicated that you have read this information and are 
willing to participate in the study. You cannot complete the survey without checking "I consent."
- I Consent
o I Do Not Consent

-Country of birth

-In which U.S. state or territory were you born?

-Country of Birth

-Ethnic origin and/or racial identity (check all that apply):

(Note: Choices are given as follows: "Black or African American," "Bangladeshi," "Carolinian," "Chamorro," "Chinese," "Chuukese," "Filipino," "Hispanic or Latino," "Japanese," "Korean," "Kosraean," "Marshallese,"

"Nepalese," "Palauan," "Pohnpeian," "Thai,, "White," "Yapese," and "Other")

-Please enter all of other ethnic origin(s) and/or racial identity/identities

-Age

-Languages spoken

[Note: Choices are given as follows: "First language," "Second language," "Third Language," "Additional languages (Please separate by comma - e.g. Spanish, Mandarin, Chamorro)"]

-Years of teaching experience

-Years of social studies teaching experience

-Years (total) you have lived in the Commonwealth of the Northern Marianas Islands

-What grade levels do you teach? (check all that apply)

(Note: Choices are given as follows: "Prekindergarten," "Kindergarten," "1ST," "2nd," "3rd," "4th," "5th," "6th," "7th," "8th," "9th," "10th," "11th," "12th," and "Post-secondary")

-Why do you think it is important to teach social studies?

-Please enter the courses you teach, and the core concepts of each. (e.g., Biology: classification, evolution, reproduction, environmental adaptations)

[Note: Sub-items for written answers are given as follows: "Course 1," "Course 1 core concepts," "Course 2," "Course 2 core concepts," "Course 3," "Course 3 core concepts," "Course 4," "Course 4 core concepts," "Additional courses (please separate with comma)"]

-To what extent do you feel your students find these core concepts meaningful and relevant? Please elaborate as much as possible.

-How would you describe a "good citizen?" 
-To what extent do you teach "citizenship" in your social studies classes? How do you do it?

-In what ways is your curriculum and teaching responsive to local culture and context?

-How familiar are you with the National Council of Social Studies (NCSS) National Curriculum Standards?

(Note: Choices are given as follows: "Very familiar," "Moderately familiar," "Slightly familiar," and "Not familiar at all")

-How frequently do you refer to the NCSS standards in the course of your work?

(Note: Choices are given as follows: "Frequently," "Occasionally/ Sometimes," "Rarely," and "Never")

-Are you familiar with the concept of "inafa maolek?"

(Note: Choices are given as follows: "Yes," "Somewhat," and "No")

-What does "inafa maolek" mean to you?

-To what extent do you feel "inafa maolek" does or doesn't fit with the aims and goals of social studies? Please explain.

-Are you familiar with the concept of "chinchule?"

(Note: Choices are given as follows: "Yes," "Somewhat," and "No")

-What does "chinchule" mean to you?

-To what extent do you feel "chinchule" does or doesn't fit with the aims and goals of social studies? Please explain.

-What do you feel are the most significant challenges facing the island in which you reside?

-Consider the following statement: The Social Studies Program integrates the social sciences and humanities to promote civic competence and participation. The curriculum is dynamic in order to prepare students for a society where change is rapid and constant. The realities of a globally interdependent world require students to understand their historical roots and draw upon historical knowledge. Students must learn to solve problems facing their local communities as well as emerging global issues. The Social Studies Standards and Benchmarks provide opportunities for students to develop skills in making not only personal choices but also economic choices based on limited resources. Students need preparation to face persistent dilemmas in our democracy. All students need to be confident in their ability as lifelong learners, 
to enter and adapt to a changing world of work and further the goals of democracy (CNMI Public Schools, 2016).

To what extent do you feel this goal is realized in your classroom? Please explain.

-For an additional \$25 Amazon gift card, would you be willing to participate in a 1 hour follow-up interview?

(Note: Choices are given as follows: "Definitely willing," "Possibly willing," and "Not willing")

-Please enter your email address in order to receive your $\$ 10$ Amazon gift card for completing this survey.

\section{Appendix B: Interview Questions}

1. What is citizenship education to you?

2. What is social studies education to you? Aims/goals?

3. Is social studies contextually relevant?

4. Is social studies a foreign idea?

5. CNMI rendering of social studies besides indigenous history?

6. What connections are made between home and social studies classes? Is it relevant for students?

7. NCSS: Is it followed at all?

8. Tailor made SSED for the CNMI? If so, how?

9. Chinchule or inafa maolek-is culture congruent to active citizenship?

10. Questions for me? 